\title{
Evaluasi Pembelajaran Pendidikan Agama Islam (Studi di SMK Muhammadiyah 1 dan SMK Muhammadiyah 2 Kota Palembang)
}

\author{
Nur Azizah, Muhammad Zainuddin
}

Universitas Muhammadiyah Palembang nurazizahpalembang11@gmail.com

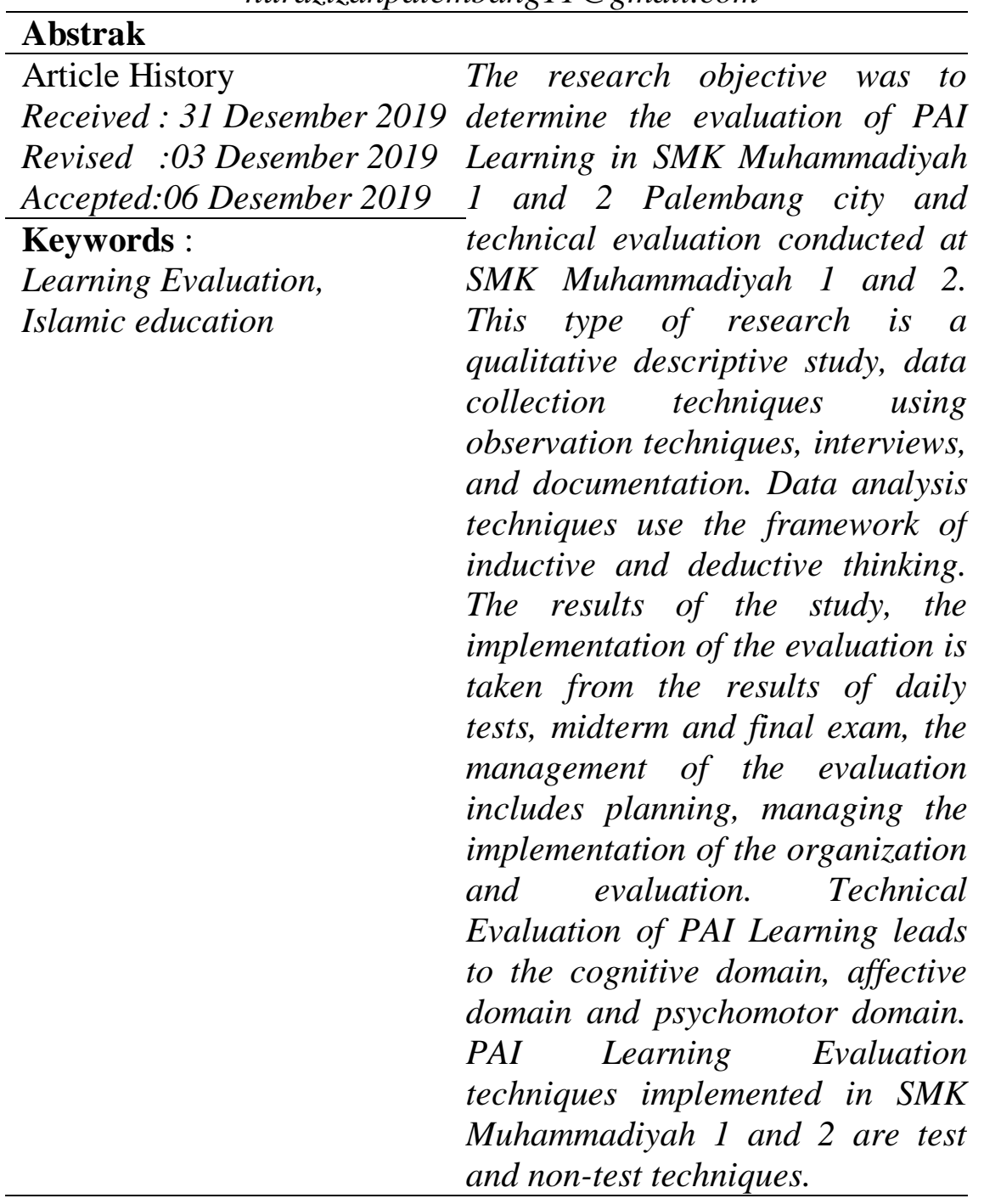




\section{Pendahuluan}

Evaluasi pembelajaran sangat diperlukan dalam kegiatan belajar mengajar, karena evaluasi adalah bagian dari perencanaan pembelajaran. Dalam Undang-Undang Republik Indonesia Nomor 20 tahun 2003 tentang Sistem Pendidikan Nasional pasal 57 aya t(1), evaluasi dilakukan dalam rangka pengendalian mutu pendidikan secara nasional sebagai bentuk akuntabilitas penyelenggara pendidikan kepada pihak-pihak yang berkepentingan, diantaranya terhadap peserta didik, lembaga, dan program pendidikan (Sukardi, 2008: 1). Dengan evaluasi pembelajaran guru akan lebih mudah untuk mendapatkan informasi dan data keberhasilan peserta didik, juga sebagai alat ukur untuk melanjutkan pembelajaran berikutnya. Selain itu juga evaluasi juga berguna untuk mengetahui metode apa yang dapat dipakai oleh guru ketika hendak melaksankan kegiatan belajar mengajar.

Menurut Wand dan Brown(1957) evaluasi sebagai “...refer to the act or process to determining the value of something"Evaluasi mengacu kepada suatu proses untuk menentukan nilai sesuatu yang dievaluasi (Wina Sanjaya, 2006: 335). Sedangkan menurut Guba dan Lincoln, evaluasi itu merupakan suatu proses memberikan pertimbangan mengenai nilai dan arti sesuatu yang dipertimbangkan. Dari konsep ini, ada dua hal yang menjadi karakteristik evaluasi. Pertama, evaluasi merupakan suatu proses. Artinya, dalam suatu pelaksanaan evaluasi mestinya terdiri dari berbagai macam tindakan yang harus dilakaukan. Dengan demikian evaluasi bukan hasil atau produk, akan tetapi rangkaian kegiatan-kegiatan. Kedua, evaluasi berhubungan dengan pemberian nilai atau arti. Artinya berdasarkan hasil pertimbangan evaluasi apakah sesuatu itu mempunyai nilai atau tidak. Dengan kata lain evalusi dapat menunjukkan kualitas yang dinilai.

Untuk suatu tujuan evalusai penting dilakukan, tetapi ada kemungkinan tidak menjadi bermanfaat lagi untuk tujuan lain, oleh karena itu seorang guru harus mengenal beberapa macam tujuan evaluasi dan syarat-syarat yang harus dipenuhi agar mereka dapat merencana dan melakukan evaluasi dengan bijak dan tepat. Evaluasi yang bain harus memenuhi persyaratan: 1) valid, 2) andal, 3) objektif, 4) seimbang, 5) membedakan, 6) norma, 7) fair, 8) praktis (Sukardi, 2008: 8). 
Penilaian merupakan salah satu komponen sistem pembelajaran., dimana penilaian adalah kegiatan akhir yang harus dilakukan untuk mengetahui keberhasilan atau ketercapaian tujuan pembelajaran yang diinginkan, karena merupakan suatu tindakan atau suatu proses untuk menentukan nilai dari sesuatu atau untuk menentukan nilai keberhasilan belajar peserta didik setalah ia mengalami proses belajar selama satu periode tertentu (Kunandar, 2010: 337). Selain itu evaluasi juga disebut sebagai proses penilaian untuk menggambarkan prestasi yang dicapai oleh seorang peserta didik sesuai dengan kreteria yang telah ditetapkan. (Muhibbin Syah, 2008: 197).

Pendapat Hamalik menjelaskan bahwa evaluasi dilakukan oleh setiap pendidik yang merupakan proses berkelanjutan tentang pengumpulan dan penafsiran untuk menilai (asses) keputusankeputusan yang dibuat dalam merancang system pembelajaran. Rumusan evaluasi tersebut mempunyai tiga implikasi yaitu: Pertama, evaluasi adalah suatu proses yang terus menerus, bukan hanya pada akhir pengajaran tetapi dimulai sebelum dilaksanakan pembelajaran sampai dengan berakhirnya pembelajaran. Kedua, proses evaluasi senantiasa diarahkan ketujuan tertentu, yakni untuk mendapatkan jawaban-jawaban tentang bagaimana memperbaiki pembelajaran. Ketiga, evaluasi menuntut penggunaan alat-alat ukur yang akurat dan bermakna untuk mengumpulkan informasi yang dibutuhkan guna membuat keputusan (Omar Hamalik, 2002: 210).

Di bidang pendidikan, evaluasi merupakan proses yang berkenaan dengan pengumpulan informasi dan data sebagai bukti untuk menentukan tingkat kemajuan pembelajaran, dan dapat medeteksi diwaktu mendatang. Evaluai dilakukan oleh pendidik adalah salah satu usaha untuk mengetahui tingkat kemampuan peserta didik juga mempermudah untuk mengkontrol jalannya proses penilai tersebut,dan berfungsi untuk mengontrol terhadap semua aktivitas yang dilaksanakan di sekolah. Pelajaran Pendidikan Agama Islam memiliki peranan amat penting dalam kehidupan manusia, dan menjadi pemandu dalam upaya mewujudkan suatu kehidupan yang bermakna, damai dan bermartabat. Didalamnya mengandung nilainilai yang dapat dikembangkan memlalui pendidikan, baik dilingkungan keluarga, sekolah maupun masyarakat. Pendidikan Agama Islam (Al-Islam) yang diselenggarakan di sekolah merupakan sebuah proses yang dalam perkembangannya adalah rumpun mata 
pelajaran yang diajarkan di sekolah maupun diperguruan tinggi (Nazaruddin, 2007: 2).

Dalam kegiatan penilaian Pendidikan Agama Islam (Al-Islam) sama saja dengan mata pelajaran lainnya. Untuk mengetahui keberhasilan peserta didik juga dilakukan penilaian melalui evaluasi sebagai proses sistematis dalam memperoleh informasi tentang keefektifan kegiatan belajar mengajar, disamping itu dapat membantu para guru dalam mencapai tujuan pembelajaran secara optimal dan juga untuk menggambarkan prestasi yang dicapai oleh peserta didik sesuai dengan kreteria yang telah ditetapkan (Muhibbin Syah, 2008: 197).

Idealnya guru melakukan penilaian dimulai dari pelaksanaan kegiatan belajar sampai akhir kegiatan belajar, seperti dilakukan prites dan postes, melaksanakan ulangan harian, melaksanakan ulangan tengah semester (UTS) dan ujian akhir semester yang dilaksanakan waktu akhir proses pembelajaran, bahkan penilaian performance (penampilan) saat dilaksanakan kegiatan diskusi dan presentasi, selain itu tugas mandiri atau tugas kelompok yang diberikan pada siswa.

Begitu juga pendidikan Islam, dalam perkembangannya berusaha membina pribadi muslim yang berpadu dari segi spiritual, jasmani, Rohani, emosi, intelektual dan sosial, sehingga tertanam akhlak yang mulia, dan dapat menjadikan manusia yang utuh, berupaya menjadikan manusia sebagai khalifah fil al-ardh, bertanggung jawab dan tetap menghambakan diri kepada Allah, terutama dalam menghadapi perkembangan teknologi di era global dan modern seperti sekarang ini, yang dapat mempengaruhi kehidupan manusia. Maka pendidikan Islam harus dipertahankan dengan utuh. Namun pada kenyataannya mata pembelajaran Pendidikan Agama Islam di sekolah masih kurang diminati oleh siswa, dan masih kurang berhasil dalam pembentukan prilaku positif pada peserta didik karena dalam pembelajaran sifatya monoton, kemudian lemahnya aspek metodologi yang dikuasai oleh guru yang merupakan penyebab rendahnya kualitas pembelajaran. Disamping itu perencanaan evaluasi pun yang direncanakan oleh guru kurang diperhatikan dalam pelaksanaannya pada hal ketika hendak mengajar guru telah mempersiapkan rencana pembelajaran dan penilaian dalam kegiatannya. Hal ini tentu sangat berpengaruh dalam keberhasilan belajar siswa. 
Dalam pengembangan evaluasi kemampuan guru sangat dituntut sesuai dengan perkembangan teknologi, seperti yang diilakasanakan di SMK Muhammadiyah di kota Palembang menggunakan evaluasi tes dan nontes, yaitu tes tertulis dan tes lisan. Alat ini digunakan untuk menilai keberhasilan peserta didik dalam penguasaan konsep, sedangkan tes praktek digunakan untuk menilai peserta didik dalam penguasaan praktek seperti pelaksanaan ibadah (shalat) atau membaca al-Qur'an (hapalan) (psikomotor). Adapun untuk menilai sikap peserta didik di sekolah menggunakan alat penilaian non tes, yaitu dengan melalui pengamatan sikap dan perilaku peserta didik di sekolah selama proses belajar mengajar berlangsung.

Penilaian pada mata pelajaran Al-Islam dilakukan tidak hanya pada kegiatan belajar mengajar dikelas saja, tetapi juga dilakukan di luar kelas, seperti penilaian akhlak pada peserta didik selama berada dilingkungan sekolah, pelaksanaan ibadah shalat yang dijadwalkan pada waktu shalat zuhur, hapalan surat pendek yang wajib diikuti siswa, serta kegiatan lainnya yang berkaitan dengan mata pelalajaran Agama Islam (Al-Islam).

Taswin, Fitriani (2016) Pelaksanaan evaluasi pembelajaran guru pendidikan agama islam pada mata pelajaran aqidah akhlak di madrasah aliyah al ittifaqiah kecamatan indralaya kabupaten ogan ilir. Tujuan penelitian ini adalah untuk mendeskrifsikan dan menggali tentang Pelaksanaan Guru Pendidikan Agama Islam terhadap pelaksanaan evaluasi pembelajaran khususnya pada mata pelajaran Aqidah Akhlak.Ulul, Ahmad Syaiful, judul Implementasi Evaluasi Pembelajaran Pendidikan Agama Islam Computer Basic Test. Tujuan penelitian ini adalah untuk mengetahui tahapan-tahapan dalam proses Implementasi Computer based test dimulai dari tahap pelaksanaan dan hasil implementai evaluasi bast test ( Studi Multisitus di SMK Negeri 2 Malang dan SMK PGRI 3 Malang). Jenis penelitian kualitatif fenomenologi naturalistik. Hasil penelitain ini menunjukkan bahwa, 1) perencanaan evaluai hasil belajar peserta didik serta online yaitu perencanaan secara teknik terhadap sistem, membuat jadwal pelaksanaan, memasukkan data guru dan peserta didik, mempersiapkan sarana dan prasarana, melakukan training. 2) melaksanakan melipuit beberapa tahapan. Tujuan penelitian adalah untuk mengetahui evaluasi Pembelajaran Pendidikan Agama Islam di SMK Muhammadiyah 1 dan 2 kota Palembang dan teknis evaluasi 
yang dilaksanakan di SMK Muhammadiyah 1 dan 2 kota Palembang dan untuk mengetahui teknis Evaluasi Pembelajaran Pendidikan Agama Islam (Al-Islam) yang dilaksanakan di SMK Muhammadiyah 1 dan 2 kota Palembang.

Manfaat penelitian adalah (1) Menambah pengetahuan penulis tentang seputar evaluasi pembelajaran pendidikan agama Islam (AlIslam) di SMK Muhammadiyah 1 dan 2 kota Palembang. (2) Sebagai sumbang saran keilmuan di SMKMuhammadiyah 1 dan 2 kota Palembang. (3) Untuk mengembangkan fikiran yang berhubungan dengan pegembangan evaluasi pembelajaran yang harus diperhatikan dan dikuasai oleh guru Pendidikan Agama Islam di SMK Muhammadiyah 1 dan 2 kota Palembang.

\section{Metode Penelitian}

Jenis penelitian ini adalah penelitian deskriptif kualitatif karena ditujukan untuk menggambarkan, menganalisis, dan menyajikan keadaan yang sebenarnya terjadi di lokasi area penelitian di sekolah tepatnya kepada guru agama Islam tentang evaluasi pembelajaran pendidikan agama Islam di SMK Muhammadiyah 1 dan 2 kota Palembang dalam pelaksanaan penelitian diharapkan penulis bisa memperoleh data yang diperlukan dalam penelitian ini. Sumber data yang dimaksud dalam penelitian adalah Data primer yaitu sumber data yang dihimpun langsung dari sumber utama yaitu guru Mata Pelajaran Pendidikan Agama Islam Kelas X di SMK Muhammadiyah 1 dan 2 kota Palembang dan data sekunder yaitu sumber data pendukung yang diperoleh dari buku-buku, jurnal.

Teknik pengumpulan datamenggunakan teknik triangulasi yang maksudnya untuk menganalisa hasil dari observasi, berbagai wawancara dengan kepala sekolah, guru, staf/karyawan, serta para siswa. Teknik Analisis Data menggunakan kerangka berfikir induktif dan deduktif atau menganalisa data yang tidak berwujud angka hanya menggunakan pola berfikir.

\section{Pembahasan}

Wawancara dilakukan pada tanggal 10 November 2019 terhadap guru Pendidikan Agama Islam (Al-Islam dan Kemuhammadiyahan) di SMK Muhammadiyah 2 sedangkan Wawancara dilakukan pada tanggal 19 November 2019 terhadap guru Pendidikan Agama Islam (Al-Islam dan Kemuhammadiyahan) di 
SMK Muhammadiyah 1. Dalam proses evaluasi pembelajaran Pendidikan Agama Islam (Al-Islam) yang dilaksanakan di SMK Muhammadiyah 1 dan SMK Muhammadiyah 2 Palembang semua Guru membuat perencanaan evaluasi pembelajaran PAI. Perencanaan evaluasi pembelajaran adalah rangkaian-rangkaian putusan yang diambil untuk menentukan sejauh mana tujuan-tujuan pengajaran telah dicapai oleh siswa.Dalam perencanaan evaluasi pembelajaran PAI di SMK Muhammadiyah 1 dan SMK Muhammadiyah 2 Palembang guru memperhatikan beberapa hal seperti: (a) tujuan dalam melaksanakan evaluasi, (b) Menyusun kisi-kisi, (c) Menulis soalUji coba dan analisis soal. (d) Revisi dan merakit soal.

Pelaksanaan evaluasi pembelajaran PAI di SMK Muhammadiyah 1 dan SMK Muhammadiyah 2 Palembang diambil dari hasil ulangan harian, Ulangan Tengah Semester dan Ulangan Akhir Semester dan untuk kenaikan kelas penilaian diambil dari pelaksanakan evaluasi pada akhir semester genap. Pelaksanaan evaluasi yang dilakukan oleh guru artinya bagaimana cara melaksanakan suatu evaluasi sesuai dengan perencanaan evaluasi, baik menggunakan tes (tes tertulis, tes lisan dan tes perbuatan) maupun non-tes. Dalam pelaksanaan tes maupun non-tes tersebut akan berbeda satu dengan lainnya, Dalam praktek, pelaksaan tes hasil belajar dapat diselenggarakan secara tertulis, lisan maupun perbuatan.Pada tes tulis, soal-soal tes dituangkan dalam bentuk tertulis dan jawaban juga dalam bentuk tulis. Pada tes lisan, soal-soal tes diajukan secara lisan dan dijawab secara lisan pula. Adapun pada tes perbuatan, wujud soal tesnya adalah pemberian perintah atau tugas yang harus dilaksanakan oleh testee dan cara penilaiannya dilakukan terhadap proses penyelesaian tugas dan hasil akhir yang dicapai setelah testee melaksanakan tugas tersebut.

Pengelolaan evaluasi pembelajaran PAI di SMK Muhammdiyah 1 dan SMK Muhammdiyah 2 Palembang dilakukan pada pengelolaan perencanaan, pengelolaan pelaksanaan, pengelolaan organisasi dan pengelolaan evaluasi. Pengelolaan dilakukan dengan cara mengubah skor standar kedalam nilai, baik berupa huruf atau angka dan melakukan analisis soal.

Aspek-aspek yang dinilai dalam evaluasi pembelajaran PAI di SMK Muhammadiyah 1 dan SMK Muhammadiyah 1 Palembang yaitu aspek kognitif, afektif dan psikomotorik. Domain kognitif meliputi pengetahuan yaitu jenjang kemampuan yang menuntut 
peserta didik untuk dapat mengenali atau mengetahui adanya konsep, prinsip, dan fakta. Pemahaman (comprehension), yaitu jenjang kemampuan yang menuntut peserta didik untuk memahami atau mengerti tentang materi pelajaranyang disampaikan guru. Penerapan ( application ), yaitu jenjang kemampuan yang menuntut peserta didik untuk menggunakan ide - ide umum. Analisis (analysis), yaitu jenjang kemampuan yang menuntut peserta didik untuk menguraikan suatu situasi atau keadaan tertentu ke dalam unsur-unsur atau kelompok pembentuknya. Sintesis (synthesis), yaitu jenjang kemampuan yang menuntut peserta didik untuk menghasilkan sesuatu yang baru dengan cara menggabungkan berbagai faktor. Evaluasi ( evaluation), yaitu jenjang kemampuan yang menuntut peserta didik untuk dapat mengevaluasi suatu situasi, keadaan, pernyataan atau konsep berdasarkan kriteria tertentu.Domain afektif (affective domain), yaitu internalisasi sikap yang menunjuk ke arah pertumbuhan batiniah dan terjadi bila peserta didik menjadi sadar dengan nilai yang diterima, kemudian mengambil sikap sehingga menjadi bagian dari dirinya dalam membentuk nilai dan menentukan tingkah laku. Domain afektif terdiri atas beberapa jenjang kemampuan, yaitu: kemuan menerima, kemampuan menanggapi, menilai, dan organisasi. Domain psikomotor ( psychmotor domain), yaitu kemampuan peserta didik yang berkaitan dengan gerak tubuh atau bagian-bagiannya, mulai dari gerakan yang sederhana sampai dengan gerakan yang kompleks. Perubahan pola gerakan memakan waktu sekurang - kurangnya 30 menit.Muscular or motor skill, meliputi: mempertontonkan gerak, menunjukkan hasil, melompat, menggerkkan, menampilkan. Manipulations of materials or object,meliputi: mereparasi, menyusun, membersihkan, menggeser, memindahkan, membentuk. Neuromuscular coordination, meliputi : mengamati, menerapkan, menghubungkan, menggandeng, memadukan, memasang, memotong, menarik, dan menggunakan.

Teknik evaluasi Pembelajaran PAI yang dilaksanakan di SMK Muhammadiyah 1 dan SMK Muhammadiyah 2 Palembang adalah teknik tes dan nontes. Tes : dilakukan dengan cara tes tertulis dan tes lisan ( menggunakan androit ) dan pada tes tertulis sudah menggunakan edumu. Non tes dilakukan dengan cara wawancara, praktek ibadah, porto polio dan observasi. Bentuk tes yang sering dipakai dalam proses belajar mengajar pada hakikatnya dapat dikelompokkan menjadi 3 kelompok, yaitu: (a) Tes lisan. Tes ini 
sering digunkan oleh guru kelas untuk mengevaluasi siswanya dengan cara memberi pertanyaan kepada siswanya. Hasilnya dapat digunakan guru untuk menambah faktor yang menentukan nilai akhir siswa. (b) Tes tertulis yaitu jenis tes dimana soal dan jawabannya dilakukan secara tertulis. Ada 2 jenis tes tertulis diantaranya: 1). Tes essay (subjektif) dan 2) Tes objektif. Adapun macam-macam tes objektif, anatara lain tes benar-salah (true-false), tes pilihan ganda (multiple choice tes), menjodohkan (matching tes) dan tes isian (completion tes). (c) Tes perbuatan atau tindakan. Instrumen evaluasi non tes dapat digunakan jika kita ingin mengetahui kualitas proses dan produk dari suatu pekerjaan serta hal-hal yang berkenaan dengan effective domain seperti sikap, minat, bakat dan motivasi. Bentukbentuknya Pengamatan (Observasi), Wawancara (interview), Angket (Questionnaire).

\section{Simpulan}

Evaluasi Pembelajaran Pendidikan Agama Islam (Al-Islam) yang dilaksanakan di SMK Muhammadiyah 1 dan 2 kota Palembang berjalan dengan baik karena semua guru membuat (a) perencanaan evaluasi pembelajaran PAI, (b) pelaksanaan evaluasi pembelajaran PAI di SMK Muhammadiyah 1 dan 2 diambil dari hasil ulangan harian, Ulangan Tengah Semester dan Ulangan Akhir Semester dan untuk kenaikan kelas penilaian diambil dari pelaksanakan evaluasi pada akhir semester genap, (c) Pengelolaan evaluasi pembelajaran PAI di SMK Muhammdiyah 1 dan SMK Muhammdiyah 2 Palembang dilakukan pada pengelolaan perencanaan, pengelolaan pelaksanaan, pengelolaan organisasi dan pengelolaan evaluasi.

Teknis Evaluasi Pembelajaran Pendidikan Agama Islam (AlIslam) yang dilaksanakan di SMK Muhammadiyah 1 dan 2 kota Palembang mengarah kepada tiga domain yaitu domain kognitif, domain afektif dan domain psikomotorik. Teknik evaluasi Pembelajaran PAI yang dilaksanakan di SMK Muhammadiyah 1 dan SMK Muhammadiyah 2 Palembang adalah teknik tes dan nontes. Tes : dilakukan dengan cara tes tertulis dan tes lisan ( menggunakan androit ) dan pada tes tertulis sudah menggunakan edumu. Non tes dilakukan dengan cara wawancara, praktek ibadah, porto polio dan observasi. 


\section{DAFTAR PUSTAKA}

Badan Penelitian dan Pengembangan Depdiknas 2003.UndangUndang: Sistem Pendidikan Nasional. Jakarta: Departemen Pendidikan Nasional.

Hawi,Akmal. 2001. Kompetensi Guru PAI. Jakarta: Rajawali Pers.

Hamalik,Omar. 2002.Perencanaan Pengajaran Berdasarkan Pendekatan Sistem. Jakarta : Bumi Aksara.

Kunandar. 2010.Guru Profsional Implementasi Kurikulum Tingkat Satuan Pendidikan dan Sukses dalam Sertifikasi Guru. Jakarta: Rajawali Pers.

Komalasari, Kokom, 2011. Pembelajaran kontektual Konsep dan Aplikasi. Bandung: Refika Aditia.

Langulung, Hasan. 2000.Asas-asas Pendidikan Islam.Edisi Revisi. Jakarta: AlHusna Zikra.

Lexy, J. Moleong. 2013.Metodologi Penelitian Kualitatif. Bandung: Remaja Rosada Karya.

Nazaruddin. 2007. Manajemen Pembelajran:Implementasi Konsep, Karateristik dan metodologi Pendidikan Agama Islam Sekolah Umum. Yoyakarta: Teras.

Sugiono. 2011. Metode Penelitian Kuantitatif Kualitatif dan $R \& D$. Bandung:Alpabeta.

Sukardi. 2008. Evaluasi Pendidikan Prisif dan Operasoinalnya.Yogyakarta: Bumi Aksara.

Sanjaya, Wina. 2006. Strategi Pembelajaran Berorientasi Standar Proses Pendidikan. Jakarta : Kencana Renada Media.

Syah,Muhibbin. 2008.Psikologi Belajar. Jakarta : PT. Raja Grasindo Persada. 
Uno, Hamzah. 2012. Perencanaan Pembelajaran. Jakarta: Bumi Aksara. 